\title{
Law Enforcement in Treating the Dark Circulation of Narcotics the Border Area of Indonesia
}

\author{
Yuhernawa $^{1}$, Megawati Barthos ${ }^{2}$ \\ Universitas Borobudur, Faculty of Law, Jakarta, Indonesia ${ }^{1,2}$ \\ \{mamatitin75@gmail.com¹, megawati_barthos@borobudur.ac.id²\}
}

\begin{abstract}
The border area is a hot spot for narcotics smuggling, through ports ranging from the eastern waters of Sumatra from Aceh to Lampung to Kalimantan, Riau and the Riau Islands, which are vulnerable to the circulation of narcotics in Indonesia because 80 percent of narcotics in Indonesia enter through this route. The smuggling of narcotics is caused by the high amount of wages for one-time methamphetamine courier who can earn Rp. 60 million to Rp. 80 million. Law enforcement against narcotics crimes through efforts to impoverish narcotics dealers still needs to construct a comprehensive and integrated criminal law system with other regulations and apply to both the national and international world. Efforts to tackle the illicit trafficking of narcotics in border areas are still needed to improve coordination with other countries which are transit places and illicit narcotics trafficking in Indonesia.
\end{abstract}

Keywords: Illicit Narcotics Circulation

\section{Introduction}

Transnational crime is a crime phenomenon that occurs across national borders and at one time is subject to two or more state jurisdictions, meaning which state jurisdiction will be applied to these crimes is determined by the territorial principle and the expansion of the territorial principle. Transnational crime in narcotics trafficking and smuggling is considered a threat to the security and stability of the world region, including in ASEAN. With a population of nearly 500 million people in Southeast Asia, this region is a potential market for international narcotics producers and dealers.

The border area is one of the most important manifestations of territorial sovereignty. Insofar as the border is expressly recognized by treaties or acknowledged in general without a clear statement, the border is part of a state's right to its territory. To eradicate the illicit trafficking of narcotics is very unlikely if it is only carried out by the government and related agencies in Indonesia, in this case the National Narcotics Agency (BNN) must cooperate with the government and related agencies of other countries, because the circulation has entered across countries. The border area is a hot spot for narcotics smuggling, through ports ranging from the eastern waters of Sumatra from Aceh to Lampung to Kalimantan, Riau and the Riau Islands, which are vulnerable to the circulation of narcotics in Indonesia because 80 percent of narcotics in Indonesia enter through this route. The smuggling of narcotics entering through border areas in Indonesia is caused by the high amount of wages for narcotics couriers of the 
type of crystal methamphetamine, the price of methamphetamine narcotics in Indonesia weighing 1 (one) gram up to Rp. 1.4 million to Rp. 1.6 million, while the wages for a one-time courier weighing 1 (one) kilogram can earn Rp. 60 million to Rp. 80 million.

The narcotics smuggling case in 2019 which was successfully revealed by the National Narcotics Agency (BNN) succeeded in uncovering 81.86 kilograms of methamphetamine and 102,657 ecstasy items from 8 suspects and 3 different crime scenes, 2 locations in Asahan Regency and 1 location in Batubara Regency. The narcotics originate from Malaysia and are brought by sea using a boat that is anchored at a small port / rat or unofficial port around the Tanjung Balai Asahan area. Then the narcotics were distributed using a private car with evidence found in three spare tires on the truck.

Combating the trafficking of narcotics and illegal drugs is one type of transnational crime. The operational modes of narcotics smuggling are increasingly diverse, including the perpetrator using the false concealment mode (hiding narcotics in an object), body wrapping (attaching narcotics to the body), and being inserted (inserting narcotics into the body).

Narcotics crime by smuggling narcotics in border areas is a form of organized crime so that in handling it applies special criminal provisions based on the lex spealis derogate lex generalis principle, which implies that specific provisions will take precedence over general provisions. Law enforcement is one of the legal structure factors that affect the effectiveness of the law. Due to the proximity of the border to other countries, its transnational nature is visible and influences law enforcement, for example the existence of a mafia or community culture in border areas whose lives are influenced by other countries.

The illicit trafficking of narcotics between Indonesia and Malaysia has reached a serious and concerning stage. Cooperation between the two countries to reduce the level of narcotics crime in their respective regions. The efforts made by the Indonesian and Malaysian governments to focus on combating narcotics in all their territories, have been carried out in prevention, law enforcement, therapy and rehabilitation, research and development, and institutional strengthening. However, these efforts have not been able to stop the transnational crime rate of trafficking of narcotics and illegal drugs from Malaysia to Indonesia. It can be assumed that transnational crimes often occur in developing countries. The supporting factors are the geographic location of the two countries which are close to each other and easily accessible by various means of transportation, the role of government officials who are not firm due to weak regulations and laws.

This can be seen in cases of illicit trafficking and narcotics abuse in border areas through "rat ports" throughout the archipelago and spreading among the people, there are even law enforcement officers who play with narcotics, both consuming and distributing them, until narcotics plunges the community. Law enforcement efforts in the context of preventing and eradicating narcotics crimes in border areas in Indonesia are handled by several agencies, namely the National Narcotics Agency (BNN), the National Narcotics Agency (BNN), the National Police, the TNI and Customs, each of which has its own interests and efforts are needed to improve coordination and supervision in prevent the entry of narcotics into Indonesia. Enforcement of criminal law in state borders and border areas has problems with its own characteristics compared to crimes committed outside the borders. This characteristic can be seen from the condition of human resources in law enforcers, infrastructure, and communities around the border area. In addition, the types of criminal acts that are categorized as organized crime, the perpetrators are more professional and difficult to carry out education.

Law enforcement problems are generally related to the legal system itself, namely the structure, substance and culture or culture of law. If these three things are fulfilled and 
synergize with each other, then law enforcement will run more effectively, which in turn will bring about social change in accordance with what is expected by the legislators or legislation.

\section{Problem Statement}

The formulation of the problem in this research is "How are efforts to overcome the illicit trafficking of narcotics in the border areas of Indonesia?"

\section{Literature Riview}

\subsection{Law Enforcement}

Law functions as a protection for human interests. In order for human interests to be protected, laws must be enforced. Law enforcement can take place normally, peacefully, but it can also occur because of lawlessness. In this case the law that has been violated must be enforced. Through law enforcement that has been violated must be enforced. It is through law enforcement that the law becomes a reality.

According to Faisal Santiago, he said that: "The law contains norms for protecting the interests of the people such as justice, freedom of choice, fair treatment, humane treatment, the right to welfare and decent work, including those with law enforcement. If the administrators of power implement the duties outlined by this law according to the will of the law, then this means carrying out the ideal objectives inherent in a rule of law such as protecting and protecting human life from harm, at least it can be said that the legal expectations have been fulfilled.”.

Based on the theory of law enforcement by Sudikno Mertokusumo, his theory states that: "In upholding the law, there are three elements that must be considered, namely: legal certainty (rechtssicherheit), benefit (zweckmassigkeit), and justice (gerechtigkeit).”. The law must be enforced and everyone expects the law to be enacted in the event of a concrete event. How the law should apply, basically it is not permissible to deviate: fiat justitia et pereat mundus (even though the world is collapsing, the law must be enforced).

\subsection{Narcotics Crime}

The criminal policy against the narcotics law focuses on the abuse and distribution of narcotics, starting from planting, production, distribution, trafficking, to their use, including personal use. The criminalization policy is in accordance with the United Nations convention on narcotics, including a criminal act stipulated regarding the act of changing or transferring / transferring wealth, which is known to have originated from narcotics crime or which originates from participating in the crime for the purpose of helping someone avoid legal consequences. , from involvement in a criminal act. As specified in Article 3 paragraph (1) UN Convention against Illicit Traffic in Narcotic Drugs and Psychotropic Substance 1988.

The United Nations Convention on Transnational Organized Crime (UNTOC) which has been ratified by Indonesia with Law Number 5 of 2009 concerning Ratification of the United Nation Convention Against Transnational Organized Crime (United Nations ConventionNation Against Transnational Organized Crime) mentions a number of crimes that fall into the category of transnational organized crime, namely money laundering, corruption, illicit trade 
in protected wild plants and animals, crimes against cultural property, human trafficking, smuggling of migrants. and the production and illicit trade in firearms. The Convention also recognizes the close relationship between transnational organized crime and terrorism crimes, although their characteristics are very different. Although the crime of illicit narcotics trafficking is not referred to in the Convention, this crime is categorized as transnational organized crime and is even more fully regulated in the three Narcotics-related Conventions prior to the signing of UNTOC.

According to Barda Nawawi Arief, stated that: "Transnational organized crime is a crime that is organized by a structured group of three or more people. The groups were organized for a specific period of time and acted together with the aim of committing one or more serious crimes or offenses. The purpose of organizing it is to obtain financial or other material benefits, directly or indirectly". Meanwhile, according to Channing May, said that: "The existence of transnational organized crime is also an implication of the natural consequences of the dynamics of the revolution in computer and internet technology. This makes it easier for the market to be involved in the transportation and communication process. In particular, the economy is globalizing so that countries become interconnected and interdependent". According to Petrus Reinhard Golose, the characteristics of transnational organized crime are as follows:

a. Hierarchically organized and sustainable;

b. Profits through evil;

c. Using violence and threats;

d. Involves corruption to maintain immunity and the law;

e. Serving the demands of the general public;

f. Monopolizing certain markets;

g. Closed membership;

h. Non-ideological in nature;

i. A specialized division of labor;

j. Have rules for maintaining confidentiality;

k. Well planned.

One of these transnational crimes is the crime of narcotics. The laws and regulations that form the basis for efforts to prevent and eradicate criminal offenses from narcotics in Indonesia are Law Number 35 of 2009 concerning Narcotics. The definition of narcotics is contained in Article 1 number 1 of Law Number 35 of 2009 concerning Narcotics, that:

Narcotics are substances or drugs derived from plants or non-plants, both synthetic and semisynthetic, which can cause a decrease or change in consciousness, loss of taste, reduce to eliminate pain, and can cause dependence, which are differentiated into groups as attached in This Act.

Meanwhile, what is meant by illicit narcotics trafficking, according to Article 1 point 6 of Law Number 35 of 2009 concerning Narcotics, that: The Illicit Circulation of Narcotics and Narcotics Precursors is any activity or series of activities carried out without rights or against the law which is determined as a criminal offense for Narcotics and Narcotics Precursor. Whereas in the provisions in Article 35 of Law Number 35 of 2009 concerning Narcotics, the definition is stated:

Narcotics Circulation is any activity or series of activities to distribute or deliver narcotics, either in the context of trading, not trafficking or transferring, for the benefit of health services and the development of science and technology. In the circulation of narcotics in Indonesia, what is meant by "without rights and against the law" is that the distribution activity is carried out without any legal documents as a condition for the existence of legal documents which are 
regulated imperatively in Article 38 of the Narcotics Law and based on the explanation of the article, what is meant with "must be completed with valid documents", is that every circulation of narcotics including the transfer of Narcotics outside the customs area to the importer's warehouse must be accompanied by documents made by importers, exporters, pharmaceutical industry, pharmaceutical wholesalers, government pharmaceutical storage facilities, housing sick, health center, clinic, doctor or pharmacy.

These documents are in the form of Import / Export Approval Letter, invoice, transport letter, letter of delivery of goods, doctor's prescription or a copy of doctor's prescription, which are an integral part of the Narcotics concerned. In an effort to prevent and eradicate narcotics, the National Narcotics Agency is given the authority based on Article 64 paragraph (1) of Law Number 35 of 2009 concerning Narcotics, that:

a. In the framework of preventing and eradicating the abuse and illicit trafficking of Narcotics and Narcotics Precursors, with this Law the National Narcotics Agency is established, hereinafter abbreviated as BNN.

b. The BNN as referred to in paragraph (1) is a non-ministerial government institution that is domiciled under the President and is responsible to the President.

According to Romli Atmasasmita stated that: "Prevention or overcoming the abuse of narcotics is an effort taken in the framework of enforcing both the use, production and illicit trafficking of narcotics that can be carried out by any person, whether individual, community and state. Narcotics crime is caused by two factors, namely factors within the perpetrator of the narcotics crime, and factors outside the perpetrator of the crime.".

\subsection{State Border Territory}

The use of the terms "region" and area are basically two different things from a legal perspective. The word "territory" in Law Number 43 of 2008 concerning State Territory, is used for "state territory", "water area" and "jurisdiction area". Meanwhile, for the border used "state boundaries" and "boundaries of jurisdiction". The area referred to in this paper is a "state boundary", that is, the boundary line separating the sovereignty of a country based on international law. Meanwhile, the term area is referred to as "border area", namely the part of the State Territory which is located on the inner side along the territorial borders of Indonesia with other countries, in the case of State Territory on land. The border area is in the subdistrict.

\section{Research Methods}

The research approach method used is normative juridical. Normative research or also called literature law research is: "Legal research is carried out by examining library materials or mere secondary data.".

\section{Treatment of Dark District of Narcotics in the Border Area Of Indonesia}

The development of the quality of criminal acts or crimes shows that territorial boundaries between one country and another in the world, both within one region and in different regions, are increasingly disappearing. At present, it is almost certain that all types or forms of crime can no longer be seen only as the criminal jurisdiction of a country, but are often claimed to 
belong to the criminal jurisdiction of more than one or two countries, so that in its development, it has created a jurisdiction conflict problem which very disturbing international relations between countries with an interest in certain criminal cases that are cross-territorial in nature.

Organized transnational crime deserves special attention. This is because Indonesia is strategically located between two continents and two oceans, making it vulnerable to various forms of transnational crime. During its development, Indonesia has paid special attention to new and developing transnational organized crime. Among them are trafficking in persons and people smuggling, corruption and money laundering, forestry and wildlife crimes, fisheries crimes, illegal trade in cultural heritage objects, as well as the abuse and smuggling of narcotics as well as perks. Trans-border crimes between two countries are crimes that seriously threaten the security and resilience of a country within the scope of international interactions. Cross-border smuggling is a logistical intensive process that can be seen as a core competency for cross-border criminal organizations involved in narcotics smuggling activities. Narcotics crimes in Indonesia are part of transnational crimes committed by professional and organized perpetrators who involve Indonesian citizens and foreign nationals. Narcotics crime is one of the means to quickly gain profits in an illegal and against the law, where in these activities there are sponsors and trained actors to carry out the narcotics business activity.

The traffickers of narcotics in the Indonesia-Malaysia border area were carried out in various ways by the perpetrators, during 2020 the North Kalimantan Provincial National Narcotics Agency (BNNP) still managed to reveal 19 kilograms of sabu-type narcotics abuse, confiscating a total of Rp. 8.9 billion and secured 27 suspects with various modes of circulation. One of them is the new modus operandi used by the perpetrators, namely hiding crystal methamphetamine in the fishpond location. The new methamphetamine smuggling was intended to trick law enforcement officers. The obstacle experienced by the North Kalimantan National Narcotics Agency in exposing the religion of narcotics smuggling is due to the involvement of inmates in the North Kalimantan Penitentiary (Lapas) because they often get rejection from the prison when they are about to investigate the perpetrators. It is very risky to enter a prison to conduct a search. However, the North Kalimantan National Narcotics Agency (BNN) is allowed to bring the inmates to be examined at the North Kalimantan BNNP office.

The illicit trafficking of narcotics is one of the crimes with an international dimension which has the characteristics of: organized crime, in the form of a syndicate, there is a large amount of financial support and the distribution utilizes sophisticated technology. The illicit trafficking of narcotics has even grown with the advancement of the telecommunications and transportation systems. The mode of illicit international narcotics trafficking always involves foreign citizens and has an impact on the territories of two or more countries and is always preceded by preparations or planning carried out outside the territorial boundaries of a particular country. At this time, Indonesia is not only a transit area/traffic of narcotics because of its strategic position. The large population, strategic geographical location and sociopolitical conditions are in the process of transition, where political stability and security are still very unstable and fragile have pushed Indonesia to become a destination for the narcotics trade. To make matters worse, in recent years Indonesia has also been indicated as a producer of narcotics. This can be seen by the disclosure of several large narcotic laboratories (clandestine labs) in Indonesia.

The causes of transnational organized crime, namely: (1) evacuation is the process of avoiding crime detection (detection facilities are still minimal); (2) corruption, colluding illegally with the government for criminal purposes (syndicate coordination in prisons), (3) confrontation, namely threatening the government to get a crime (weak supervision and law 
enforcement). The causes of the smuggling of narcotics at the Entikong border between Indonesia and Malaysia, namely (4) conflicting policies between countries, (5) a new mode of smuggling at the international level, and (6) the rat road as a narcotics route in the Entikong border area of Indonesia and Malaysia.

Narcotics smuggling has also attracted the interest of many people because it is considered a business that promises huge coffers of profits. Illegal narcotics trafficking is no longer carried out by individuals alone but has even been carried out by international syndicates. The syndicate distributes illegal narcotics and spreads to almost all regions. In the circulation and trafficking of illegal narcotics, these syndicates use various modus operandi to be able to smuggle the narcotics illegally to a country. The modes and techniques used by these flocks of illegal narcotics traffickers continue to experience developments in tandem with the development of technological media and also current means of communication.

Narcotics crimes, which are part of organized crime, are basically one of the crimes against development and crimes against social welfare which are the center of national and international attention and concern. This is very reasonable, considering that the scope and dimensions are so broad, that its activities carry the characteristics of organized crime, whitecollar crime, corporate crime, and transnational crime. Transnational crime is a threat to the state and society, therefore it is the state's obligation to maintain security and order. One form of transnational crime which is crucial because it transports the future of a nation's generation, especially among the young generation of this country, is crimes in the field of narcotics abuse. The modus operandi of narcotics trafficking syndicates can easily penetrate national borders in the world through a neat management network and sophisticated technology and enter Indonesia.

Currently, the government is aggressively fighting narcotics abuse, the use of narcotics is transnational (transnational criminality) because it can cross national borders (borderless countries) by using sophisticated modus operandi and technology, with a neat management network, and supported also by a wide network of organizations, then entering Indonesia as a transit state or even as a destination country for illegal narcotics trafficking (point of market state) and it has caused many victims, especially among the young generation of the nation to an alarming level. Endangering the joints of the life of the community, nation and state, the perpetrators of narcotics abusers are basically divided into two categories, namely the perpetrator as the dealer and the perpetrator as a user.

The border area is more often the entry point for narcotics from neighboring countries. The circulation of narcotics in border areas tends to increase, even though several related agencies work in border areas, namely the National Narcotics Agency, the Regional Police, and Customs and Excise. However, only the Police and the National Narcotics Agency have the task of investigating and investigating, while Customs and Excise are not investigating narcotics cases. Although the coordination between the Police, the National Narcotics Agency and other agencies, such as Customs and Excise and the Indonesian Navy, has been running well. However, in dealing with the smuggling or illicit trafficking of narcotics, officials in border areas still face problems, including a lack of budget and facilities and infrastructure. Therefore, this matter needs the attention of the Government because of the many rat trails that the perpetrators pass without any supervision.

Law enforcement is essentially a process to bring legal objectives into reality. However, law enforcement is still considered weak, seen from the perspective that criminal law enforcement in Indonesia is very unique and multidimensional and destructive as in the case of narcotics abuse. Many law enforcers are also affected and even become perpetrators of these narcotics crimes. In addition, with the existence of a criminal justice system mafia, the 
perpetrators seem immune from the law and feel protected. This condition illustrates that law enforcers have an influence on being free and the current rampant circulation of narcotics is ongoing and never stops. Therefore, in handling narcotics crimes, the involvement of elements of the community is needed so that they can assist and support efforts to prevent and eradicate drug abuse and narcotics smuggling, especially through the border areas of Indonesia and Malaysia.

In the border area Entikong and Sarawak have a direct relationship that needs each other even though the economy of the Malaysian border region is more advanced. This has become a whip for the management of Indonesia's border areas as well as a large comparison of the development of the border economy. The Entikong border community implements international trade activities at the Entikong border based on consumptive behavior which is influenced by the conditions of the more modern Malaysian border which has become an attraction for the socio-economic orientation of the people in the Entikong border area. The consumptive behavior of the Indonesian border community tends to go to Malaysia even though both of them have a relationship in meeting the economic needs of each border area and cause dependence between the two. Furthermore, the handling of rampant drug smuggling has prompted the Indonesian government to take action to close all rat trails at the border.

The problems faced by law enforcement officials in the case of narcotics smuggling in the border areas of Indonesia and Malaysia can be seen from the lack of clarity of the apparatus and the lack of early detection equipment at the border, making it easy for individuals to carry out drug trafficking. International-scale smuggling by sea is usually taken from Thailand to Indonesia via western or eastern Malaysia. Meanwhile, the air route is taken from Thailand or Malaysia to the International Airport in Indonesia. After arriving in Indonesia, the illegal drugs were circulated in Indonesia through a syndicate of user groups. Seeing this fact, the Indonesian border area is still weak in control and there are still many routes that can be taken to enter Indonesian territory, causing many routes to be the choice of narcotics illicit trafficking syndicates.

The mouse path has been around since the community's ancestors. The route of the rat road was originally designed to facilitate community activities prior to the establishment of state boundaries. People interpret the term rat road as referring to a path that connects from a village or hamlet in Indonesia to a village in Malaysia. Several points of intersection between the border between Indonesia and Malaysia are used as a mouse pathway, namely (1). Suruh Tembawang Village (Indonesia) to Sabit Village (Malaysia) or vice versa; (2). Palaasang Village (Indonesia) to Kampung Sadir (Malaysia) or vice versa; (3). Dusun Mapai (Indonesia) to Kampung Tepoi (Malaysia) or vice versa; (4). Peripin Hamlet (Indonesia) to Kampung Kujang Saung (Malaysia) or vice versa; (5) PLBN Entikong left and right (Indonesia) to Kampung Pang Amu and Kampung Mapu (Malaysia) or vice versa; and (6), Dusun Pangah (Indonesia) to Kampung Mapu (Malaysia) or vice versa. However, at this time the location was actually being made back by the elements to smuggle narcotics.

Law enforcement in uncovering and cutting off network syndicates trafficking and illicit narcotics trafficking, both on a national and international scale, carries out the case handling process, from investigations to prisons consistently in order to reveal the motives of crimes of abuse and illicit narcotics that have been confiscated, as well as monitoring and control over the availability and distribution of precursors and confiscation of assets belonging to perpetrators of trafficking and narcotics illicit trafficking.

In efforts to prevent and eradicate narcotics network syndicates not only arrest the perpetrators and confiscate and destroy their narcotics evidence, but BNN also imposes even more severe sanctions through the impoverishment of narcotics dealers by confiscating their 
assets and assets by implementing the Law Law Number 35 of 2009 concerning Narcotics and Law Number 8 of 2010 concerning the Crime of Money Laundering. This can be shown from the results obtained in 2019, BNN has succeeded in uncovering 55 cases and arrested 59 perpetrators and confiscated the assets of the narcotics dealers worth Rp. 184 billion.

The National Narcotics Agency (BNN) is a non-ministerial government institution that is located under the President and is responsible to the President. The National Narcotics Agency as an independent institution is expected to work better and be transparent and accountable in combating narcotics crimes. The $\mathrm{BNN}$ is also expected to be optimal in providing protection to the community and increasing international cooperation so that the transnational narcotics network can be destroyed. The role of the National Narcotics Agency if it is related to the prevention of narcotics crime is a reality that cannot be released, in accordance with Presidential Regulation Number 23 of 2010 concerning the National Narcotics Agency, namely:

a. Formulate and implement national policies regarding the prevention and eradication of the abuse and illicit trafficking of narcotics and narcotics precursors;

b. Prevent and eradicate the abuse and illicit trafficking of narcotics and narcotic precursors;

c. Coordinate with the National Police Chief of the Republic of Indonesia in the prevention and eradication of the abuse and illicit trafficking of narcotics and narcotics precursors;

d. Increase the capacity of the medical rehabilitation and social rehabilitation institutions for narcotics addicts, both organized by the government and the community;

e. Empowering the community in preventing the misuse and illicit trafficking of narcotics and narcotics precursors;

f. Monitor, direct and improve community activities in preventing the abuse and illicit trafficking of narcotics and narcotics precursors;

g. Undertaking bilateral and multilateral cooperation, both regionally and internationally, to prevent and eradicate the illicit trafficking of narcotics and narcotics precursors;

h. Develop a narcotics laboratory and narcotics precursors.

i. Carry out administrative investigations and investigations into cases of abuse and illicit trafficking of narcotics and narcotics precursors;

j. Make an annual report on the implementation of duties and authorities.

Basically, the Indonesian government itself through the National Narcotics Agency (BNN) has tried to suppress the increase in drug crimes, although these efforts have not been able to make the Indonesian government continue to hold back the increase. There is still an increase in drug crimes, but the Indonesian government continues to strive to produce the number of suspects and drug cases whose increase is not so sharp. The obstacles / obstacles faced by the National Narcotics Agency (BNN) in overcoming the circulation of narcotics in the border area of Indonesia - Malaysia are as follows:

a. The Interdiction Task Force (Satgas) has not yet been established in the border area between Indonesia and Malaysia to prevent the smuggling and illicit trafficking of narcotics by the international network into West Kalimantan. The Interdiction Task Force consists of West Kalimantan Provincial BNN officers, the Police, Customs and Excise, and Immigration Officers who will be stationed at places suspected of being entrances to international narcotics networks.

b. The unavailability of sophisticated tools that work automatically to detect incoming narcotics using the border crossing between West Kalimantan (Indonesia) and Sarawak (Malaysia). 
c. The number of illegal lanes / roads (there are about 55 rat roads) between the border of West Kalimantan (Indonesia) and Sarawak (Malaysia) with a land border length of about 966 kilometers, making it difficult to detect the illicit trafficking of narcotics by the international network.

International cooperation between countries will certainly bring about meaningful changes and be more effective if it is placed within the framework of cooperation in the prevention and control of the illicit trafficking of narcotics under the coordination of world bodies such as the United Nations (UN) for example, or related UN organs. with that thing. Because what has happened so far in general, the methods for overcoming illicit narcotics trafficking are carried out individually or solely between the two countries considered to be the source and target of the narcotics distribution. The fundamental weakness of this kind of cooperation is the lack of coordination with other countries, for example, which become a transit point for circulation and trade. In addition to collaborating with BNN, the United Nations Office on Drugs and Crime (UNODC) is also collaborating with other Indonesian government agencies through the BNN. This is done so that relevant Indonesian government agencies such as POLRI (Indonesian National Police), TNI (Indonesian National Army), Director General of Customs and Excise, and the Ministry of Political, Legal and Security Affairs can work together in tackling cases of smuggling or illegal narcotics trafficking at the border of Indonesia and Malaysia. and strengthen its supervision.

In combating the circulation of narcotics from within the country and abroad, the Indonesian Government established the National Narcotics Agency (BNN). The formation of the National Narcotics Agency (BNN) itself is based on a predetermined legal basis, which is stated in the Presidential Decree of the Republic of Indonesia Number 17 of 2002 which was later replaced by Presidential Regulation Number 83 of 2007 and revised again with the Presidential Regulation of the Republic of Indonesia Number 23 of 2010 concerning National Narcotics Agency. The National Narcotics Agency (BNN) is a non-structural institution under and directly responsible to the President, which only has the task and function of coordinating. In Law Number 35 of 2009 concerning Narcotics, the position of the National Narcotics Agency (BNN) was upgraded to a non-ministerial government institution (LPNK) and strengthened its authority to carry out investigations and investigations. In addition, the National Narcotics Agency (BNN) also has representatives in provinces and districts / cities as vertical agencies, namely the provincial BNN and district / city BNN.

Meanwhile, the functions of the National Narcotics Agency (BNN) are as follows:

a. Coordinating related government agencies in the preparation and formulation of policies in the field of availability and P4GN;

b. Coordinating related government agencies in implementing policies in the field of availability and P4GN as well as solving problems in carrying out tasks;

c. Coordinating related government agencies in the activities of procurement, control and supervision in the field of narcotics, psychotropic substances, precursors and other addictive substances;

d. The operation of a task force consisting of related government elements in P4GN is in accordance with their respective duties, functions and authorities;

e. Termination of the illicit network of narcotics, psychotropic substances, precursors and other addictive substances through the task force;

f. Implementing national, regional and international cooperation in the context of overcoming the problem of narcotics, psychotropic substances, precursors and other addictive substances. 
g. Implementing national, regional and international cooperation in the context of overcoming the problem of narcotics, psychotropic substances, precursors and other addictive substances;

h. BNP and BNK / City organizing is related to the implementation of policies in the P4GN sector.

Furthermore, the National Narcotics Agency (BNN) has the following objectives:

1. The achievement of a high commitment from all components of government and society to fight drugs.

2. The realization of the attitudes and behavior of the community to participate in the prevention and eradication of drug abuse and trafficking.

3. The realization of law enforcement conditions in the field of drugs in accordance with the rule of law.

4. Achieved improved systems and methods in the treatment and rehabilitation of drug abusers.

5. Compilation of an accurate database on drug abuse and trafficking.

6. The operation of the task forces that have been formed based on the situation analysis.

7. The role of the Provincial / Regency / City Narcotics Agency in implementing the P4GN program.

8. The establishment of effective international cooperation that can provide solutions for handling drug problems in Indonesia.

Prevention efforts have been carried out with the construction of six integrated posts in a number of areas that are considered vulnerable, one of which is West Kalimantan. These posts prevent the vulnerable points of entry of Narcotics into Indonesia. Then the need for law enforcement is an effort to eradicate suppressing and reducing its demand, as well as weapons for members of the National Narcotics Agency (BNN) which are used to eradicate the circulation of narcotics.

The National Narcotics Agency has seen several rat roads around the Entikong PLBN where the West Kalimantan-Malaysia land border is 965 kilometers long. Hundreds of shortcuts are vulnerable and dangerous to the smuggling of narcotics. Entikong is often questioned as the entry and exit of narcotics, even though not all narcotics cases are smuggled through Entikong. Not only land and water routes, air routes are also one of the media that needs attention. Because there have been many cases of narcotics smuggling, which fortunately were thwarted by customs and excise at the local airport. Especially now that these dealers often pass the investigation because the modus operandi and tactics used are increasingly diverse.

According to the Head of the West Kalimantan Provincial National Narcotics Agency (BNNP), the network of illegal drug smugglers is known to be led by prisoners who are currently in prison who bring the drugs from China through several shipping points including Malaysia and Singapore. The drugs can enter Indonesia after shipping goods from a number of countries including Malaysia. It is known that drug shipments from Kuching, Malaysia to Indonesia were carried out through the Entikong border.

Delivery of prohibited goods and services in a variety of situations, illegal goods and services such as illegal status, strict regulations, or high taxes where suppliers and customers are trying to find legal loopholes. Apart from the supply of illegal goods and services, organized crime is linked to theft, robbery, fraud, 'predation' and so on. Criminal organizations are also linked to organized crime because criminal groups know each other, socialize, cooperate, even come into conflict with other criminal groups. 
According to the Head of the West Kalimantan National Narcotics Agency, there are as many as eleven countries that supply narcotics to Indonesia before landing in Indonesia. The narcotics first transited in Singapore and Malaysia. All supplies from world countries end in Indonesia through two sub-transit countries, namely Malaysia and Singapore. Until now, Indonesia has still not been able to cooperate with the two countries to uncover the large narcotics network. One of the reasons is because of collided regulations in each country. For example, rules regarding law enforcement that cannot be carried out in that country. Narcotics smuggling activities are not only due to geographical factors that benefit transnational criminals but also the driving factors that accommodate this activity. Narcotics smuggling is driven by a network of organizations that seek profit by becoming intermediaries.

Narcotics intermediaries referred to in Law Number 35 of 2009 concerning Narcotics are people who deliver or pick up narcotics from abroad to be delivered to someone or somewhere in Indonesia by smuggling narcotics, either through airports or seaports. Qualified as a carrier or delivery (intermediary) is a person who carries, sends, transports or transits narcotics without rights and against the law individually or in an organized manner, whereas what is meant by a dealer is a person who imports, exports, offers for sale, distributes, becomes buyers, deliver, receive, become intermediaries in buying and selling. Or exchange narcotics without rights and against the law individually or in an organized manner.

The illicit trafficking of narcotics does not only come from within the country, but also comes from abroad either by land, sea or air routes. The illicit trafficking of narcotics through land routes generally occurs around the Indonesian border area with the surrounding countries. This can occur due to weak surveillance and security systems in border areas. Inadequate facilities and infrastructure as well as a lack of attention from the central party towards policies around the border areas have triggered gaps between people in the area around the border with Indonesian people in the city. This is what encourages people around the border to look for other ways to be able to make a living, even though they have to do something that is against the law.

\section{Conclusion}

Law enforcement in tackling the illicit trafficking of narcotics in border areas as a critical point for the circulation of narcotics into Indonesia through unofficial ports and the high wages of methamphetamine narcotics couriers have made efforts to prevent and eradicate narcotics network syndicates by the National Narcotics Agency (BNN) through efforts to impoverish dealers narcotics by confiscating assets and assets through the application of the Narcotics Law and the Money Laundering Law, it is still necessary to establish a criminal law system in the form of a law which is comprehensively regulated and integrated with other regulations and applies to both the national and international world.

In carrying out efforts to combat the illicit trafficking of narcotics in border areas, the National Narcotics Agency has a weakness in the development of illicit narcotics trafficking in border areas, especially at the Indonesia - Malaysia border because the Interdiction Task Force (Satgas) has not been formed in the border area, and the number of routes between the border between West Kalimantan (Indonesia) and Sarawak (Malaysia) which is still needed efforts to improve coordination with other countries that are a stopover for the illegal trafficking of narcotics in Indonesia. 


\section{References}

[1] Arief, Barda Nawawi, Kapita Selekta Hukum Pidana, (Bandung: Citra Aditya Bakti, 2010).

[2] Arifin, Saru. Hukum Perbatasan Darat antar Negara. (Jakarta: Sinar Grafika, 2014).

[3] Atmasasmita, Romli. Tindak Pidana Narkotika Transnasional dalam Sistem Hukum Pidana Indonesia, (Bandung: PT Citra Aditya Bhakti, 2002).

[4] Badan Narkotika Nasional, Press Release Akhir Tahun 2019.

[5] Golose, Petrus Reinhard. "Kejahatan Transnasional dan Radicalism". STIK-IK Angkatan II, 16 Januari 2013.

[6] Ismail, Chairuddin. Kapita Selekta Penegakan Hukum Tindak Pidana Tertentu, (Jakarta: PTIK Press, 2007).

[7] Mattaliti, Abdurrachman, dkk. Kerjasama ASEAN dalam Menanggulangi Kejahatan Lintas Negara, (Jakarta: Direktorat Jenderal Kerjasama ASEAN Departemen Luar Negeri RI, 2001).

[8] Mertokusumo, Sudikno. Mengenal Hukum (Suatu Pengantar), (Yogyakarta : Cahaya Atma Pustaka, 2010), hal. 207.

[9] Padmanegara, Garda T.. Sekilas tentang Kejahatan Transnasional, (Jakarta: Riset Hukum Kejahatan Transnasional, 2008)

[10] Soekanto, Soejono dan Sri Mamudji, Penelitian Hukum Normatif (Suatu Tinjauan Singkat), (Jakarta: RajaGrafindo Persada, 2014).

[11] Undang-Undang Nomor 35 Tahun 2009 tentang Narkotika.

[12] Elyta. "Penyelundupan Narkoba di Perbatasan Entikong Indonesia dan Malaysia". (Andalas Journal of International Studies, Col. IX, No. 2, November 2020, DOI: https://doi.org/10.25077/ajis.9.2.100-115.2020

[13] Klaus von Lampe, Organized Crime: Analyzing Illegal Activities, Criminal Structures, and Exrtrea-Legal Governance, Sage Publication, 2016.

[14] May, Channing. "Transnational Crime and the Developing World: Global Financial Integrity", (Global Financial Integrity, June 2016, 2017).

[15] Prayuda, Rendi. Cifebrima Suyastri dan Dhani Akbar. "Transnasional Terorganisir di Wilayah Perbatasan: Studi Modus Operandi Penyelundupan Narkotika Riau dan Malaysia", (Andalas Journal of International Studies, Vol. IX No. 1, 2020) < https://doi.org/10.25077/ajis.9.1.34-47.2020 >.

[16] Ratih Nur Istiqomah. "Strategi Hubungan Indonesia dengan Malaysia dalam Mewujudkan Drug Free ASEAN 2015”, (Journal of International Relations, Vol. 2, No. 1, 2016).

[17] Santiago, Faisal. Penegakan Hukum Tindak Pidana Korupsi oleh Penegak Hukum untuk Terciptanya Ketertiban Hukum, Pagaruyuang Law Journal Volume 1 No. 1, Juli 2017.

[18] T. Kramer. "The Current State of Counter-narcotics Policy and Drug Reform Debates in Myanmar". (Journal Transnational Institute, Vol. 6 No. 1, 2015).

[19] Zhang, Sheldon and Ko-Lin Chin, "Enter the Dragon: Inside Chinese Human Smuggling Organizations', Criminology, 40.4 (2002), 737-68< https://doi.org/10.1111/j.1745-9125.2002.tb00972.x >.

[20] Hadiani, Siti. "Kendala BNNP Kaltara Mengungkap Peredaran Narkoba di Perbatasan". https://www.liputan6.com/regional/read/4450864/kendala-bnnp-kaltaramengungkap-peredaran-narkoba-di-perbatasan $>$. 
[21] Julianto, Pramdia Arhando, "Impian Mentan Amran Wujudkan Wilayah Perbatasan Jadi Lumbung Pangan“, Kompas, $10 \quad$ April 2017 < http://ekonomi.kompas.com.com/read/2017/04/10/205551226/impian.mentan.amran.w ujudkan.wilayah.perbatasan.jadi.lumbung.pangan $>$.

[22] Otey, Melvin., et.al, "International and Transnational Crime and Justice', International and Transnational Crime and Justice, $2019<$ https://doi.org/10.1017/9781108597296 $>$.

[23] Susahnya Menangkap Bandar Narkoba di Wilayah Perbatasan RI-Malaysia, diakses melalui https://tirto.id/susahnya-menangkap-bandar-narkoba-di-wilayah-perbatasan-rimalaysia-cPY2 tanggal 28 November 2020.

[24] Padmanegara, Makbul R. Kejahatan Internasional, Tantangan dan Pemecahan, (Majalah Interpol Indonesia, 2007). 